\title{
Antioxidant enhancing ability of different solvents extractable components of Talinum triangulare in some selected Tissue homogenates of Albino Rats -In vitro
}

\author{
Olakunle Bamikole Afolabi ${ }^{1 *}$, Omotade Ibidun Oloyede ${ }^{2}$, Isreal Idowu Olayide ${ }^{1}$, Tajudeen Olabisi Obafemi ${ }^{1}$, \\ Obabiolorunkosi Joseph Awe ${ }^{1}$, Blessing Ariyo Afolabi ${ }^{3}$, Amos Sunday Onikani $^{1}$ \\ ${ }^{1}$ College of Science, Department of Biochemistry, Afe-Babalola University. P.M.B 5454, Ado-Ekiti, Ekiti State, Nigeria. \\ ${ }^{2}$ Faculty of Science, Department of Biochemistry, Ekiti State University. P.M.B 5363, Ado-Ekiti, Ekiti State, Nigeria. \\ ${ }^{3}$ Department of Biochemistry, Bowen University, Iwo, Osun State. Nigeria.
}

\section{ARTICLE INFO \\ Article history: \\ Received on: 11/06/2015 \\ Revised on: 24/07/2015 \\ Accepted on: 23/08/2015 \\ Available online: 27/09/2015}

\section{Key words:}

Antioxidants, Talinum

triangulare, Catalase,

Superoxide dismutase,

Reduced glutathione.

\begin{abstract}
Antioxidant contents, mostly from plant source have been the major combating components against membranous peroxidation that causes degenerative diseases and among others in the living cells. In this work, we did look into how ethanol and aqueous extractable components of Talinum triangulare could effectively and synergistically enhance the activities of antioxidant enzymes i.e superoxide dismutase (SOD) catalase (CAT) and reduced glutathione (GSH) activities in the different tissues used in vitro. Different methods were employed in the assay and the results showed significant $(\mathrm{p}<0.05)$ increase in ethanolic extract when the GSH enhancing competencies were considered in the organs when compare with that of aqueous and relatively with the control, also, the levels of catalase activities (CAT) observed showed significant $(\mathrm{p}<0.05)$ difference as observed in the organs. Considering the superoxide dismutase (SOD) activities, aqueous extract showed significant $(\mathrm{p}<0.05)$ increase in the liver and brain while significant $(\mathrm{p}<0.05)$ increase was only observed in the ethanolic extract in the kidneys tissue. Indisputably, it could be claimed based on these facts that, Talinum triangulare could enhance the activities of these antioxidant enzymes assayed for and in turns could be helpful in the phytotherapeutic management of common diseases associated with the hypoactivity of the enzymes when involve in the diet.
\end{abstract}

\section{INTRODUCTION}

The widespread usage of medicinal plants in different area and components of life has led to the curiosity of scientists in the infinite findings and researches of every constituent and effects of these various diversified medicinal plants to nature (Afolabi and Oloyede, 2014). In the world of different diseases, the medicinal plants have been able to cure, prevent and maintain the adverse effects of different disease symptoms. Free radicals are responsible for causing a large number of diseases including cancer and human body has a complex system of natural enzymatic and non-enzymatic antioxidant defenses which neutralize the destructive effects of free radicals and other oxidants (Kinnula and Crapo, 2004). The World Health

* Corresponding Author

Olakunle Bamikole Afolabi, College of Science, Department of Biochemistry, Afe-Babalola University. P.M.B 5454, Ado-Ekiti, Ekiti State, Nigeria.Email: afolabioblessed10@yahoo.com
Organization defines traditional medicine as the sum total of knowledge, skills and practices based on the theories, beliefs and experiences aboriginal to different cultures (WHO, 2008). Hence, there is a necessity to know the effects and competencies of different extraction approaches to medicinal plants in nature because the complexity of herbal and botanical preparations is that they are not pure compounds, and it is a function of the traditionally-held bound belief that the synergistic combination of several active principles in some herbal preparations is responsible for their beneficial effects (Yadav et al., 2010). Talinum triangulare (T. triangulare) is from the family of Portulacaceae popularly known as water leaf, a perennial deciduous herb which has woody stems and succulent leaves. It has been researched to possess antioxidant property (Afolabi et al., 2014), and also used in the treatment of diseases with the presence of minerals including calcium, magnesium and potassium, omega-3-fatty acid and vitamin $\mathrm{C}, \mathrm{E}$ and $\beta$-carotene have been identified to be responsible for the antioxidant activity of the leaf (Ezekwe et al., 2013). 
Water leaf has been implicated medically in the management of cardiovascular diseases like stroke, obesity, etc. and conventionally used as softener of vegetable species. It is one of the most locally consumed vegetable and constituent of a sauce in Nigeria and has no direct food value to wildlife (Aja et al., 2010). Due to diversity in the mode of action and metabolism of different organs like kidney, liver and brain, the level of free radicals attack and its consequences differs on them and also, the reaction of antioxidants against the free radicals to prevent or cure the adverse effect to be caused by the presence of free radicals varies.

Free-radicals and the reactive oxygen species (ROS), have been known to be involved in cancer, diabetes, cardiovascular diseases, neurodegenerative diseases, ageing and various liver, kidney and brain diseases; hence, it is believed that antioxidant agents like Catalase, Superoxide Dismutase and Glutathione etc. are helpful for treatment and prevention (Halliwell and Gutteridge, 1999). A dismutase is an enzyme that catalyses the reaction of two identical molecules to produce molecules in different oxidative states. In the absence of SOD, two superoxide ions can spontaneously dismutate to produce hydrogen peroxide and singlet oxygen. SOD catalyses a reaction between two superoxide ions to produce hydrogen peroxide and triplet oxygen. In the other hand, Catalase catalyses the formation of water and free oxygen from hydrogen peroxide. Catalase is present in membrane-limited organelles known as peroxisomes.

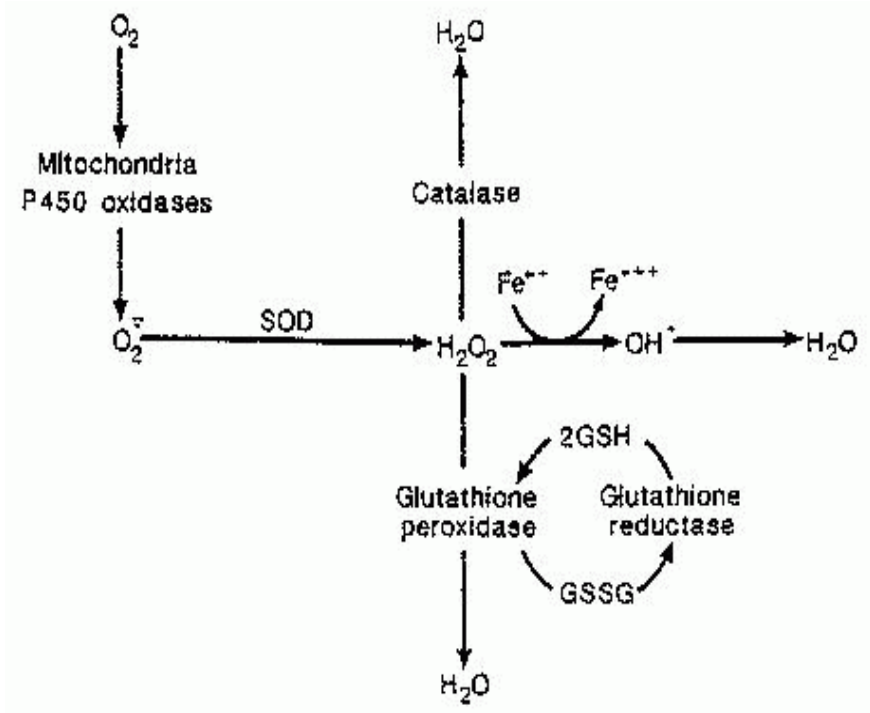

Fig.1: Summary of Antioxidant enzymes actions.

Peroxisomes contain enzymes that degrade amino acids \& fatty acids producing hydrogen peroxide as a by-product. Glutathione, a tripeptide which is composed of the amino acids cysteine, glycine and glutamic acid and also, the major antioxidant in the non-lipid portion of cells in most of the cytoplasm (Danyelle et al., 2003). It exists in a reduced form (GSH) and an oxidized form (GSSG) as shown in the Fig. 1 (Lauterburg, 1984). In addition to neutralize free radicals, glutathione is responsible for maintaining the antioxidant activity of other antioxidants, stabilizing its reduced form. One of the basic functions of glutathione is to maintain the sulfhydryl groups of proteins in the reduced state and inhibition of oxidation by hydrogen peroxide (Kałużny and Jurgowiak, 1996). Some numbers of researches have indicated that many polysaccharides extracted from plants possess potent antioxidant abilities (Amorim et al., 2013). In addition, the processing and extraction methods for medicinal plants affect its efficiency when used up in the body system for a particular purpose. Different solvents employed in the extraction of these plants components determine its potency. Some commonly used extracts solvents include aqueous and ethanol solvents and the level of these solvents extraction from plants differs due to their chemical components. Basically, ethanol has been shown to extracts more components from a particular plant when compared to aqueous extraction method. As a result to the diverse importance of the $T$. triangulare, research is needed to be done to study the enzymatic antioxidant enhancing ability of different solvents extractable components of $T$. triangulare leafs in order to observe which type of extract is more potent in the world of free radicals and antioxidants.

\section{MATERIALS AND METHODS}

\section{Plant materials and preparation}

Fresh water leaves, Talinum triangulare were bought in Ado-Ekiti, Ekiti State, Nigeria. A sample was taken to the Department of Plant Science in Ekiti State University, Ado-Ekiti, Ekiti State, Nigeria for identification, it was identified by a taxonomist in the department and allotted to it the Herbarium number UHAE 2013/76, after proper taxonomic investigations from the data base.

\section{Chemicals}

Chemicals and reagents used were all of analytical grades and prepared using sterilized distilled water.

\section{Preparation of Tissue Homogenates}

The rats were sacrificed by cervical dislocation. Liver, brain and kidney tissues were quickly removed and placed on ice. Each of the tissues was homogenized in cold $0.1 \mathrm{M}$ Tris- $\mathrm{HCl}$ buffer pH7.4 $(1: 5 \mathrm{w} / \mathrm{v})$ in a Teflon homogenizer. The homogenates were centrifuged for $10 \mathrm{~min}$ at $3000 \mathrm{~g}$ to yield a pellet that was discarded and the supernatant was used for the assay.

\section{Preparation of Sample}

\section{Preparation of Ethanolic extract}

The leaves (edible) parts of the plant were air-dried in a ventilated place at ambient temperature of $30 \pm 2^{\circ} \mathrm{C}$ for 15 days pulverized using a laboratory blender and the fine powders obtained stored at moderate temperature until further use. $120 \mathrm{~g}$ of the powdered sample was weighed and used for the extraction with $1 \mathrm{~L}$ solvent combination of $70 \%$ ethanol for $72 \mathrm{~h}$. The crude extract 
was later subjected to bioassay analysis. From the stock solution, different concentrations were obtained.

\section{Preparation of Aqueous extract}

$50 \mathrm{~g}$ of the powdered sample was extracted in $500 \mathrm{ml}$ distilled water for $48 \mathrm{~h}$. The crude extract was later subjected to bio-assay analyses. From the stock solution, different concentrations were obtained respectively. These were stored until further use. The percentage yield of the extracts was calculated as follows.

\section{Catalase Activity Assay}

The method described according to Cohen et al., 1970 (Cohen et al., 1970) was used in the determination of Catalase Activity. $0.5 \mathrm{ml}$ aliquot of extract -homogenate was added to ice cold tubes. Reaction started by adding $5 \mathrm{ml}$ of $30 \mathrm{mMH}_{2} \mathrm{O}_{2}$. Tube contents were then mixed thoroughly by inversion. Reaction was stopped after $3 \mathrm{~min}$ with $1 \mathrm{ml}$ of $6 \mathrm{M} \mathrm{H} 2 \mathrm{SO} 4.7 \mathrm{ml}$ of $0.01 \mathrm{M}$ potassium permanganate $(\mathrm{KMnO} 4)$ was then added and absorbance read at $480 \mathrm{~nm}$ within $30-60 \mathrm{sec}$.

Catalase Enzyme activity $=\underline{\text { Absorbance } / \min \times \mathrm{V} \times 1000}$

\section{$\mathrm{M} \times \mathrm{v} \times \mathrm{W}$}

Absorbance is read at $480 \mathrm{~nm} \mathrm{~V}=$ total volume of the reaction mixture; $M=$ molar extinction coefficient which is 40.0, $\mathrm{W}=$ Weight of tissue; $\mathrm{v}=$ volume of sample used.

\section{Superoxide Dismutase Activity Assay}

Superoxide dismutase (SOD) catalyzes the dismutation of superoxide into oxygen and hydrogen peroxide. The superoxide dismutase activity was determined by the method described by Misra and Fridovich (Misra and Fridovich, 1972). An aliquot of the sample was added to $2.5 \mathrm{ml}$ of $0.05 \mathrm{M}$ carbonate buffer $(\mathrm{pH}$ 10.2) to equilibrate in the spectrophotometer. The reaction was initiated by the addition of $0.3 \mathrm{ml}$ of freshly prepared $0.3 \mathrm{mM}$ adrenaline to the mixture which was quickly mixed by inversion. The reference cuvette contained $2.5 \mathrm{ml}$ buffer, $0.3 \mathrm{ml}$ of substrate (adrenaline) and $0.2 \mathrm{ml}$ of water. The increase in absorbance at $480 \mathrm{~nm}$ due to the adrenochrome formed was monitored every 30 $\mathrm{sec}$ for $150 \mathrm{sec}$. One unit of SOD activity was given as the amount of SOD necessary to cause $50 \%$ inhibition of the oxidation of epinephrine to adrenochrome during $150 \mathrm{sec}$.

\section{Calculation:}

Increase in Absorbance(per min. $)=(\mathrm{A} 3-\mathrm{A} 0) / 2.5$

$\mathrm{A}_{0}=$ absorbance after 30 seconds

$\mathrm{A}_{3}=$ absorbance after 150 seconds

$\%$ Inhibition $=\frac{\text { Increase in absorbance of substrate }}{\text { Increase in absorbance of blank }} \times 100$

1 unit of SOD activity was defined as the amount of SOD necessary to cause $50 \%$ inhibition of the oxidation of adrenaline to adrenochrome during $1 \mathrm{~min}$.

\section{Determination of Reduced Glutathione (GSH)}

The level of reduced glutathione (GSH) in the samples was determined by the method described by Jollow et al. (Jollow et al, 1974). $0.2 \mathrm{ml}$ of the sample was added to $1.8 \mathrm{ml}$ of distilled water and $3 \mathrm{ml}$ of the precipitating reagent was mixed with the sample. The mixture was then allowed to stand for 5 mins and then filtered. At the end of the fifth minutes, $1 \mathrm{ml}$ of the filtrate was added to $4 \mathrm{ml}$ of $0.1 \mathrm{M}$ phosphate buffer and finally, $0.5 \mathrm{ml}$ of the Ellmans' reagent was added. A blank was prepared with $4 \mathrm{ml}$ of the $0.1 \mathrm{M}$ phosphate buffer, $1 \mathrm{ml}$ of diluted precipitating solution and $0.5 \mathrm{ml}$ of the Ellman's reagent. The optical density was measured at $412 \mathrm{~nm}$.

GSH concentration was proportional at that wavelength and the estimate was obtained from the GSH standard curve $(\mu \mathrm{g} / \mathrm{ml})$.

\section{Statistical analysis}

The results of replicate readings were pooled and expressed as mean \pm SD. One way analysis of variance was used to analyze the results and Duncan multiple tests was applied for the post hoc (Zar, 1984). Statistical package for Social Science (SPSS) 10.0 for Windows was used for the analysis. The $\mathrm{IC}_{50}$ was calculated using non-linear regression analysis. The $\mathrm{p}$ value $<0.05$ was considered statistically significant in the analytical data.

\section{RESULTS}

The results below were pulled out from the assay above were expressed and graphically annotated in Fig. 2-10 below.

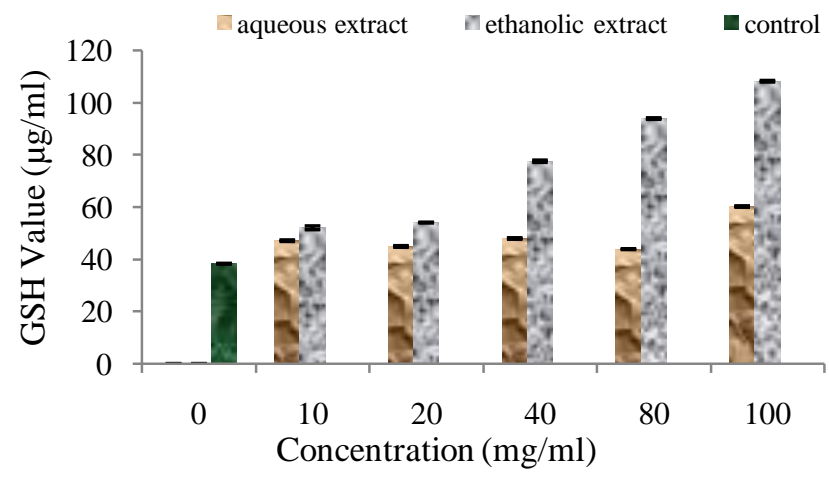

Fig. 2: The glutathione activity of the extracts in the kidney of the rats compared to control was summarized. There was significant $(p<0.05)$ increase showed in ethanolic extract with potent level of glutathione activity in a concentration dependent manner when compared with the control test.

The ethanol extract exhibited IC50 value at $25.07 \mathrm{mg} / \mathrm{ml}$ and aqueous extracts showed IC50 value at $70.14 \mathrm{mg} / \mathrm{ml}$. The values are expressed as Mean \pm S.E. Fig.3 summarizes the glutathione activity of the extracts in the brain of the rats compared to that of control. There was significant $(\mathrm{p}<0.05)$ increase showed in ethanolic extract with high potential level of glutathione activities in a concentration dependent manner when compared to the control test. The ethanol extract exhibited IC50 
value at $53.39 \mathrm{mg} / \mathrm{ml}$ and aqueous extracts showed IC50value at $73.39 \mathrm{mg} / \mathrm{ml}$. The values are expressed as Mean \pm S.E. Fig.4 summarizes the glutathione activity of the extracts in the liver of the rats compared to control test. There was significant $(\mathrm{p}<0.05)$ increase showed in ethanolic extract with potent level of glutathione activity in a concentration dependent manner when compared to the control test. The ethanol extract exhibited IC50 value at $15.87 \mathrm{mg} / \mathrm{ml}$ and aqueous extracts showed IC50 value at $75.08 \mathrm{mg} / \mathrm{ml}$. The values are expressed as Mean \pm S.E.

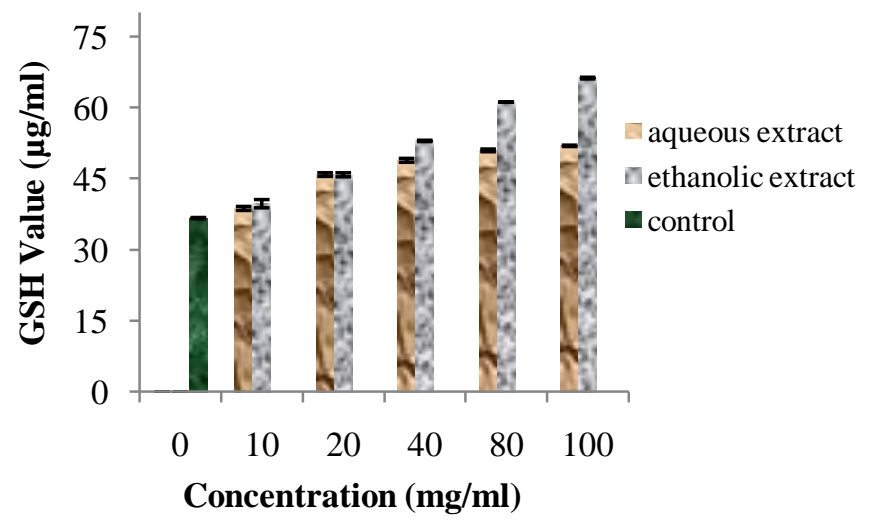

Fig. 3: The glutathione activity of the extracts in the brain of the rats compared to that of control. Therewas significant $(p<0.05)$ increase showed in ethanolic extract with high potentiallevel of glutathione activities in a concentration dependent manner when compared to the control test.

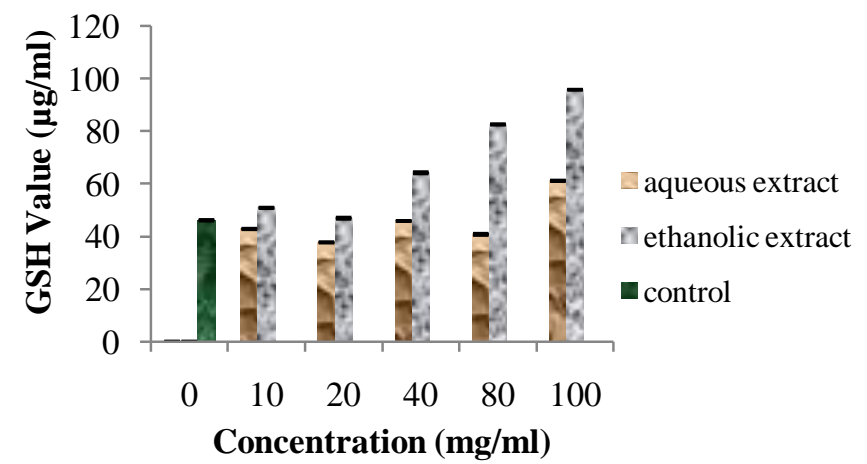

Fig.4: The glutathione activity of the extracts in the liver of the rats compared to control test. Therewas significant $(\mathrm{p}<0.05)$ increase showed in ethanolic extract with potent level of glutathione activity in a concentration dependent manner when compared to the control test.

Fig.5 summarizes the catalase activity of the extracts in the liver of the rats compared to control test. There was significant $(\mathrm{p}<0.05)$ difference showed in both the extracts in various concentrations used in the levels of catalase activities at all concentrations when compared to the control test. The values are expressed as Mean \pm S.E. Fig. 6 summarizes the catalase activity of the extracts in the brain of the rats compared to control test. There was significant $(\mathrm{p}<0.05)$ difference showed in both the extracts in various concentrations used in the levels of catalase activities at all concentrations when compared to the control test. The values are expressed as Mean \pm S.E. Fig. 7 summarizes the catalase activity of the extracts in the kidneys of the rats compared to control test. There was significant $(\mathrm{p}<0.05)$ difference showed in both the extracts in various concentrations used in the levels of catalase activities at all concentrations when compared to the control test. The values are expressed as Mean \pm S.E.

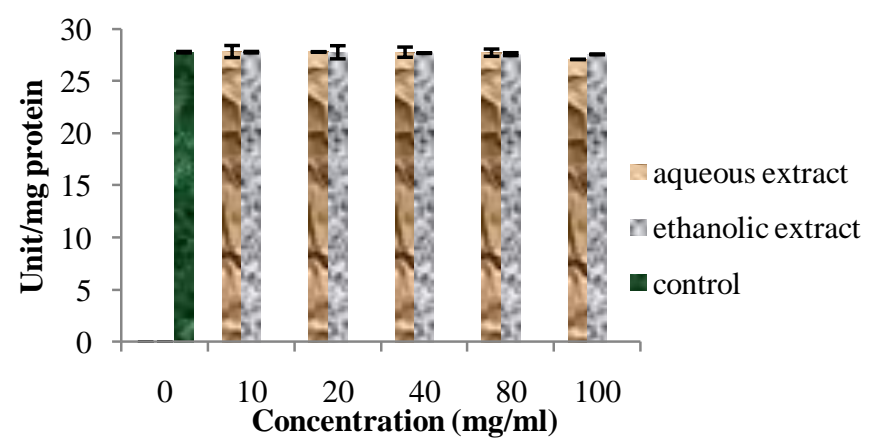

Fig. 5: The catalase activity of the extracts in the liver of the rats compared to control test. Therewas significant $(\mathrm{p}<0.05)$ difference showed in both the extracts in various concentrations used in the levels of catalase activities at all concentrations when compared to the control test

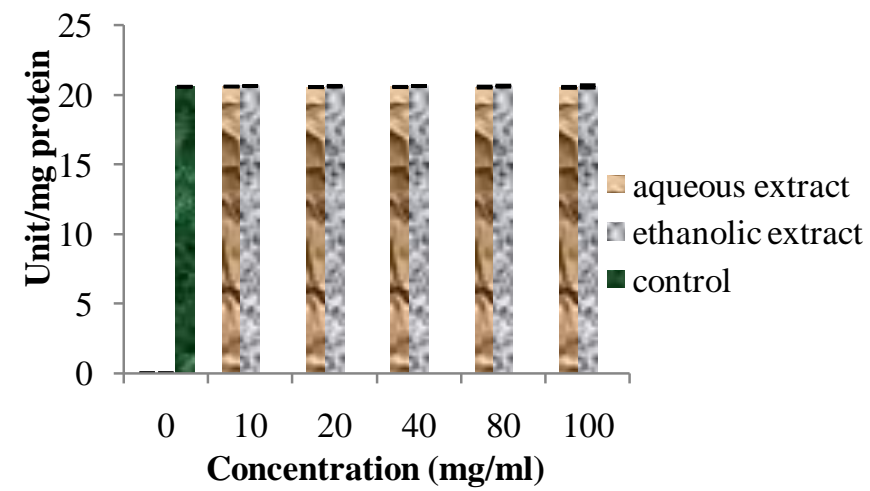

Fig. 6: The catalase activity of the extracts in the brain of the rats compared to control test. Therewas significant $(\mathrm{p}<0.05)$ difference showed in both the extracts in various concentrations used in the levels of catalase activities at all concentrations when compared to the control test.

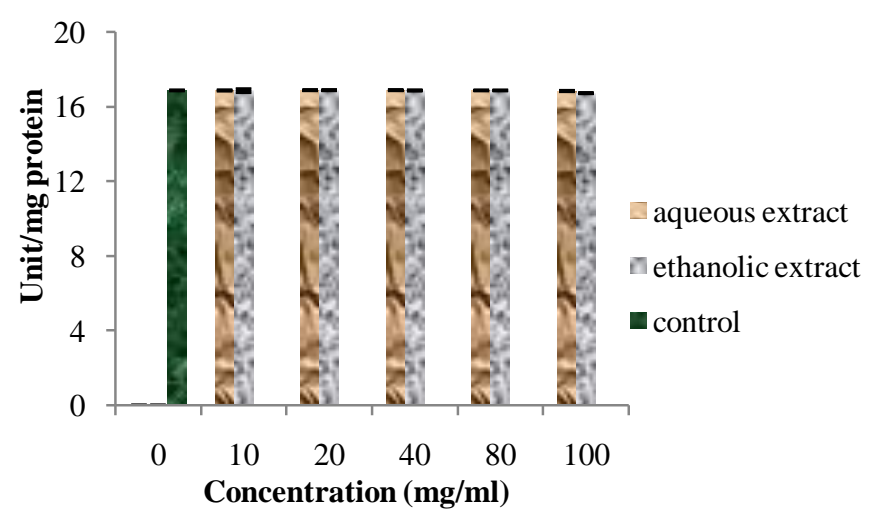

Fig. 7: The catalase activity of the extracts in the kidneys of the rats compared to control test. There was significant $(\mathrm{p}<0.05)$ difference showed in both the extracts in various concentrations used in the levels of catalase activities at all concentrations when compared to the control test.

Fig. 8 shows the effects of the extracts on superoxide dismutase activity in the liver of the rats compared to the control test. The extracts showed potent level of superoxide inhibitory activity in a concentration dependent manner when compared to the control test with significant $(p<0.05)$ increase in the aqueous 
extract. The aqueous extract exhibited $\mathrm{IC}_{50}$ value at $44.60 \mathrm{mg} / \mathrm{ml}$ and ethanol extracts showed $\mathrm{IC}_{50}$ value at $64.93 \mathrm{mg} / \mathrm{ml}$.

The values are expressed as Mean \pm S.E. Fig. 9 summarizes the superoxide dismutase activity of the extracts in the brain of the rats compared to the control test. The extracts showed potent level of superoxide scavenging activity in a concentration dependent manner when compared to control test with significant $(\mathrm{p}<0.05)$ increase in aqueous extract in the level of superoxide scavenging activity. The aqueous extract exhibited $\mathrm{IC}_{50}$ value at $38.06 \mathrm{mg} / \mathrm{ml}$ and ethanol extracts showed $\mathrm{IC}_{50}$ value at 81.51 $\mathrm{mg} / \mathrm{ml}$.

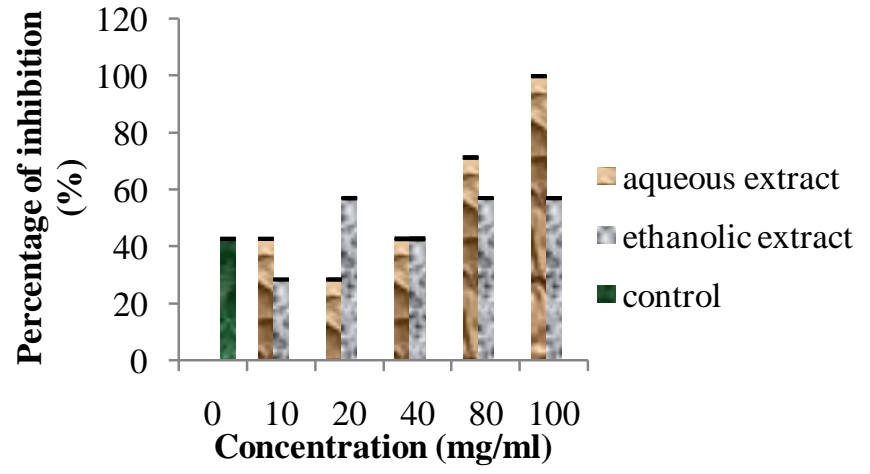

Fig. 8: The effects of the extracts on superoxide dismutase activity in the liver of the rats compared to the control test.The extracts showed potent level of superoxide inhibitory activity in a concentration dependent manner when compared to the control test with significant $(\mathrm{p}<0.05)$ increase in the aqueous extract.

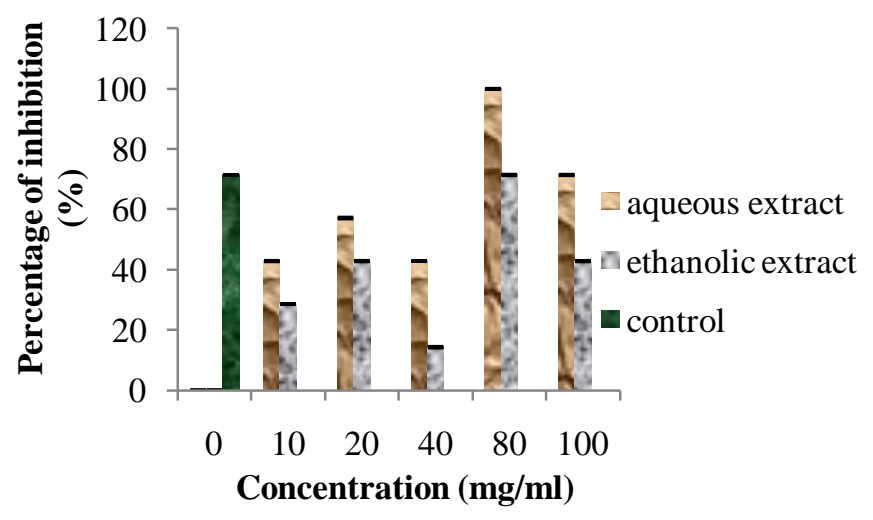

Fig. 9: The superoxide dismutase activity of the extracts in the brain of the rats compared to the control test. The extracts showed potent level of superoxide scavenging activity in a concentration dependent manner when compared to control test with significant $(\mathrm{p}<0.05)$ increase in aqueous extract in the level of superoxide scavenging activity

The values are expressed as Mean \pm S.E. Fig. 10 summarizes the superoxide dismutase activity of the extracts in the kidney of the rats compared to the control test. The extracts showed potent level of superoxide scavenging activity in a concentration dependent manner when compared to the control, with ethanolic extract showing significant $(\mathrm{p}<0.05)$ difference in the level of superoxide scavenging activity. The ethanol extract exhibited $\mathrm{IC}_{50}$ value at $165.98 \mathrm{mg} / \mathrm{ml}$ and aqueous extracts showed $\mathrm{IC}_{50}$ value at $243.8 \mathrm{mg} / \mathrm{ml}$. The values are expressed as Mean \pm S.E.

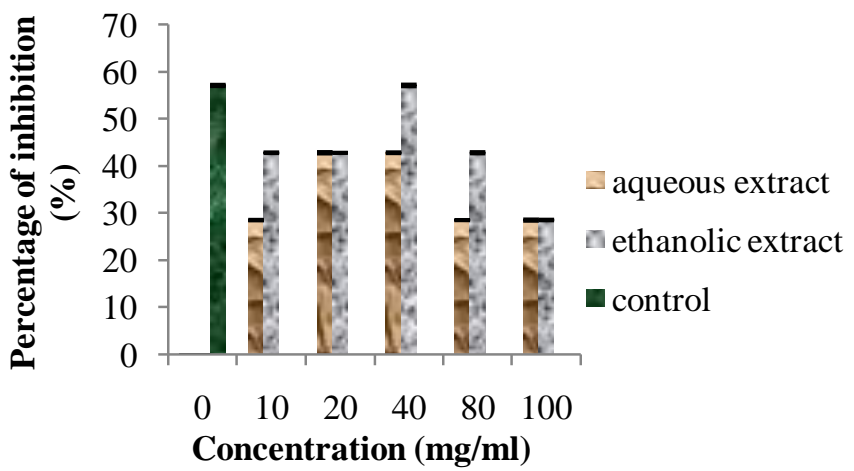

Fig. 10: The superoxide dismutase activity of the extracts in the kidney of the rats compared to the control test. The extracts showed potent level of superoxide scavenging activity in a concentration dependent manner when compared with the control, with ethanolic extract showing significant ( $\mathrm{p}<$ $0.05)$ difference in the level of superoxide scavenging activity.

\section{DISCUSSION}

In vitro assay carried out in this study was based on various strong evidences from researches which have shown that most of the biological actions and medicinal properties of plant foods are linked to the presence of secondary metabolites that are capable of inducing antioxidant potentials in humans. The polyphenolic contents by which compounds exert their antioxidant properties by scavenging free radicals, chelating metals, reducing action and inhibition of lipid peroxidation (Molehin and Adefegha, 2014), are the major involving factor in this wise. Thus, it could be inferred that the phenolics content present in $T$. triangulare contribute to the antioxidant property (Afolabi and Oloyede, 2014). Ethanolic extract of $T$. triangulare showed high values in most antioxidant activity assays carried out when compared to the control test in all organs experimented from Fig 2-10. Glutathione, a key intracellular tripeptide thiol that is composed of glutamic acid, cysteine, and glycine, which helps to protect the cells from free radical damages by acting as an antioxidant (Sapakal et al., 2008).In oxidative stress, it is an important antioxidant which helps to maintain exogenous antioxidants such as vitamins $\mathrm{C}$ and $\mathrm{E}$ and also involved with the breakdown of peroxides as described by Jollow et al. (Jollow et al., 1974). It was clearly elucidated in the experiment carried out; there was an appreciable increase in the amount of glutathione noted in the extracts in a concentration dependent manner when compared to the control test most especially in the ethanolic solvent extraction. In the liver, brain and kidney, the ethanolic extract exhibited the lowest $\mathrm{IC}_{50}$ value and hence showed the best glutathione activity in a dose dependent manner (Fig 2-4).

One of the most efficient ways of scavenging peroxide is through the enzyme catalase, which is encoded by a single gene, and is highly conserved among species (Reimer, 1994). Mammals express catalase in all tissues and a high concentration of catalase can be found in the liver, kidneys and erythrocytes (Deisseroth and Dounce, 1970). In the assay, there were appreciable concentrations of catalase induced in the two extracts of $T$. triangulare when incubated with the homogenates compared to the control test (Fig 5-7). 
At all concentrations experimented, the activities of catalase induced by all the extracts were at a very close range in the brain, kidney and liver, thus showing a satisfactory observable amount of catalase induction in all the three organs at various extract concentration.

Moreover, from Fig. 8-10, the extracts showed a potent superoxide scavenging abilities in a concentration dependent manner when compared with the control test. Superoxide anion which is the initial free radical and a weak oxidant that ultimately produces stronger oxidative species such as singlet oxygen specie and hydroxyl radical (Chandana et al., 2014). In the liver and the brain, aqueous extract exhibited the lowest $\mathrm{IC}_{50}$ value and hence showed the best superoxide radical scavenging activity but in the kidney the ethanolic extract presented more radical scavenging abilities with a lower $\mathrm{IC}_{50}$ value than that of the aqueous extract.

\section{CONCLUSION}

The objective of the study was to determine the antioxidant and free radical scavenging potential of the leaves of $T$. triangulare and also to provide a comparative analysis between the ethanol and aqueous extracts of the plant as a free radical scavenger to specify the extract with a better scavenging potential. According to the findings, the ethanol extract showed the highest antioxidant enzyme inducing properties in a dose dependent manner as compared to the aqueous extracts. As we know that free radicals are important contributors to several severe pathological conditions, the findings suggest that the extracts of the leaves of the plant is equally useful as a source of natural antioxidants with subsequent health benefits and could be more potent in action when extracted with the organic solvent Ethanol.

\section{ACKNOWLEDGMENT}

The authors hereby acknowledge the Management of Afe-Babalola University for allowingthe authors to carry out this in vitro work in the Laboratory used.

\section{REFERENCES}

Afolabi OB, Oloyede OI, Jaiyesimi KF, Obafemi TO, Awe JO and Fadaka AO. Antagonistic potentials of Talinum triangulareextracts against iron ii - induced oxidative stress in tissue homogenates of wistar albino rat - in vitro. World J Pharm Pharm Sci. 2014; 4 (6) 59-67.

Afolabi OB, Oloyede OI. Antioxidant Properties of the Extracts of Talinum triangulareand its Effect on Antioxidant Enzymes in Tissue Homogenate of Swiss Albino Rat.ToxicolInt 2014; 21:307-13.

Aja PM, Okaka AN, Onu PN, Ibiam U, Urako AJ. Phytochemical Composition of Talinum triangulare(Water Leaf) Leaves. Pakistan J Nutr. 2010; 9 (6): 527-530.

Amorim PA, Campos de Oliveira MC, Amorim $\mathrm{T}$ and Echevarria A. Antioxidant, Iron Chelating and Tyrosinase Inhibitory Activities of Extracts from Talinum triangulare Leach Stem. Antioxidants. 2013; 2: 90-99.

Chandana CB, Suparna S, Anindhya SD, Anindita T, Nayan JH, Acheenta GB, Ananta MB, and Iswar BA. Comparative study of the in vitro antioxidant property of different extracts of Acoruscalamus Linn. J natural prod plant res. 2014; 4 (1): 8-18.
Cohen D, Dembiec D, Marcus J. Measurement of catalase activity in tissue extracts. Annals Biochem. 1970; 34, 30-38.

Danyelle MT, Kenneth DT, Haim T. Dossier: Oxidative stress pathologies and antioxidants. Biomed \& Pharm. 2003; 57: 145-155

Deisseroth A and Dounce AL. "Catalase: physical and chemical properties, mechanism of catalysis and physiological role." Physiol Rev. 1970; 50: 319-375.

Ezekwe CI, Okoro IJ, Ugwu PC and Ezea SC. The effect of methanol extract of Talinum triangulareon some selected hematological andKidney parameters of experimental rats. World J Pharm Pharm Sci. 2013; 2(6): 4383-4396.

Halliwell B, Gutteridge J. (Eds.). 1999. Free Radicals in Biology and Medicine, Oxford University Press, New York, pp. 105245.

Jollow DJ, Mitchell JR, Zampaglione N and Gillete JR. Bromobenzene-induced liver necrosis, Protective role of glutathione and evidence for 3,4-bromobenzene oxide as the hepatotoxic metabolite. Pharmacol. 1974; 11, 151-169.

Kałużny J, Jurgowiak M. Udziałreaktywnych form tlenu w patogeneziewybranychchoróboczu. (Participation of reactive oxygen species in the pathogenesis of eye diseases) Klin.ocz. 1996; 98: 145.

Kinnula VL, Crapo JD. Superoxide dismutases in malignant cells and human tumors Free Radic. Biol. Med.2004; 36:718-744

Lauterburg BH, Adams JD, Mitchell JR. Hepatic glutathione homeostasis in the rat: efflux accounts for glutathione turnover. Hepatology. 1984; 4: 586-590.

Misra HP, Fridovich I.The role of superoxide anion in the autoxidation of epinephrine and a simple assay for superoxide dismutase.J BiolChem 1972; 247: 3170-5.

Molehin OR and Adefegha SA. Comparative study of the aqueous and ethanolic extract of Momordicafoetidaon the phenolic content and antioxidant properties. Inter Food Res J. 2014; 21(1): 401-405.

Reimer DL, Bailley J, Singh SM. "Complete cDNA and 5' genomic sequences and multilevel regulation of the mouse catalase gene." Genomics.1994; 21:325-336.

SapakalVD, ShikalgarTS, Ghadge RV,Adnaik RS, Naikwade NS, MagdumCS. In vivo screening of antioxidant profile: a review $\mathrm{J}$. Herbal Med. Toxicol. 2008; 2 (2):1-8.

World Health Organization (WHO). 2008. Department of Noncommunicable Diseases Surveillance. Definition, Diagnosis and classification of Diabetes Mellitus and its Complications.P 620.

Yadav M, Vikram NK and Sharma D. Complimentary and comparative study on hypoglycaemic and antihyperglycaemic activity of various extracts of Eugenia jambolana seed, Gymmemasylvestre and Trigomellafoenumgraecum seeds in rats. Applied Biochem Biotech.2010; 160: (8) 238-400.

Zar JH. 1984. Biostatistical analysis 2nd ed.: Prentice-Hall, Englewood Cliffs, 718 p.

\section{How to cite this article:}

Afolabi OB, Oloyede OI, Olayide II, Obafemi TO, Awe JO, Afolabi BA, Onikani SA. Antioxidant enhancing ability of different solvents extractable components of Talinum traingulare in some selected Tissue homogenates of Albino Rat-In vitro. J App Pharm Sci, 2015; 5 (09): 056-061. 